co e o tratamento curativo passa por eliminar a fator traumático e por excisão cirúrgica, com taxas de intercorrência e recidiva muito baixas.

http://doi.org/10.24873/j.rpemd.2017.12.054

\section{\#023 Distração osteogénica no encerramento de fenda palatina unilateral - caso clínico}

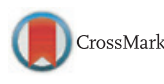

Sandra Ferreira, António Bettencourt Lucas*, Adriana Guimarães, Inês Alexandre Neves Francisco, Luísa Maló, Francisco Fernandes do Vale

Pós-graduação em Ortodontia da FMUC, Departamento de Cirurgia Maxilo-Facial, Centro Hospitalar e Universitário de Coimbra,

Introdução: A fenda lábio palatina é uma malformação congénita anatómica da região da cabeça. A sua etiologia é multifatorial, sendo que a componente genética representa $25-30 \%$ dos casos. A sua prevalência é $52 \%$ em fendas unilaterais esquerdas, $24 \%$ em fendas unilaterais direitas e $24 \%$ em fendas bilaterais. O objetivo deste trabalho é apresentar a resolução de uma fenda palatina extensa através da distração osteogénica.

Descrição do caso clínico: Paciente com 18 anos do sexo feminino, procurou tratamento ortodôntico para correção da posição dentária, fenda palatina e motivos estéticos. Não apresentava história clínica médica significativa. O exame clínico e radiológico revelaram uma Classe III esquelética por retrognatia maxilar com fenda palatina unilateral esquerda extensa.

Discussão e conclusões: Através da terapêutica selecionada foi possível realizar o encerramento total da fenda unilateral esquerda. A distração osteogénica permitiu a formação gradual de osso no local do corte bem como o aumento do volume de tecido gengival na zona da fenda, o que seria difícil de obter através de enxertos. Em casos de fendas palatinas muito extensas, o enxerto ósseo pode ser realizado sem sucesso. A principal vantagem da distração osteogénica é permitir-nos uma distensão gradual das estruturas, eliminado o risco de perda do enxerto por hipovascularização. A distração osteogénica é uma opção viável quando a fenda palatina é demasiado extensa para encerramento com enxerto, apresentando maior quantidade de formação de tecido ósseo e gengival, possibilitando uma reabilitação da zona anterior estética com maior sucesso.

http://doi.org/10.24873/j.rpemd.2017.12.055

\section{\#024 Remoção de Implante Dentário localizado} no Seio Maxilar

Gonçalo Nuno Abreu de Amorim e Castilho*, Luís Monteiro, Sérgio Barreto, José Júlio Pacheco, Pedro Moura, Rui Coelho

Foramen Dental Education, Instituto Universitário de Ciências da Saúde

Introdução: A reabilitação de maxilares edêntulos com próteses implanto-suportadas tornou-se uma prática relativamente comum, nas últimas décadas, por médicos dentistas e cirurgiões. Algumas complicações associadas a implantes como infeção, não osteointegração e migração do implante estão descritas na literatura. De entre os maiores problemas associados à presença de um corpo estranho, como é o caso de um implante dentário, no interior do seio maxilar destaca-se a sinusite, podendo levar a condições mais graves como a pansinusite, panoftalmite e celulite orbitaria. Existem duas técnicas, por excelência, para a remoção de um implante localizado na cavidade sinusal e para tratar infeções associadas a este corpo estranho: abordagem intraoral com a criação de uma janela antero-lateral de acesso ao seio maxilar ou através de uma via transnasal por técnica endoscópica.

Descrição do caso clínico: Um paciente de 67 anos de idade, sem complicações de saúde relevantes, foi encaminhado por um colega para a remoção de um implante dentário com locator que migrou para o seio maxilar direito. O implante migrou para o seio maxilar, 3 meses depois da sua colocação, durante o aperto do locator no mesmo. A cirurgia foi realizada um mês depois da migração do implante. O paciente sentia alguma dor no lado direito da face e tinha a sensação de um objeto em movimento dentro do seio maxilar. Foi realizada profilaxia antibiótica (Amoxicilina 2gr) 1h antes da cirurgia. Para a remoção do implante foi efetuada, com piezo, uma janela lateral vestibular. A cavidade do seio maxilar foi preenchida com 'collagen foam' para promover uma melhor cicatrização da membrana de Scheider. Para a fixação da janela óssea foi usada uma placa de osteossíntese e, de seguida, foi suturado o retalho com polipropileno 5,0.1 ano depois da cirurgia o paciente encontra-se sem qualquer tipo de sintomatologia.

Discussão e conclusões: A migração de um implante dentário para o seio maxilar pode provocar graves problemas infecciosos, sendo recomendável a sua remoção. A remoção de um implante do seio maxilar, através da criação de uma janela lateral vestibular, parece ser uma técnica previsível e segura. http://doi.org/10.24873/j.rpemd.2017.12.056

\section{\#025 Carcinoma Verrucoso}

Sérgio Barreto*, Rita Teixeira, Suzel Coelho, Catarina Pires, Gonçalo Nuno Abreu de Amorim e Castilho, Luís Monteiro

DSBClinic, Instituto Universitário de Ciências da Saúde

Introdução: Carcinoma Verrucoso é uma variante rara, bem diferenciado, de carcinoma de células escamosas, que não metastisa, tendo um padrão de crescimento local lento, contínuo, exofítico, de aspeto verrucoso, com bordos bem delimitados que tendem a invadir de forma local. Não se dissemina ao sistema linfático e nem à distância.

Descrição do caso clínico: Os autores apresentam um caso clínico de um doente do género masculino, com 70 anos, encaminhado para a consulta de Medicina Oral, devido a tumefação na língua, com uma evolução de 1 ano. Ao exame intra-oral, foi observado tumefação de carácter exofítica e vegetante, de consistência fibrosa, sem aderências, no bordo direito, do 1/3 médio da língua, com aproximadamente $2 \mathrm{~cm}$ no sentido ântero-posterior e de $1 \mathrm{~cm}$ de altura. O doente foi submetido a biópsia incisional. O relatório anatomopatológico descreve a lesão como alterações hiperplásicas reativas, em relação com presença de fungos, compatíveis com 'cândida'. Propôs-se a repetição do 